\title{
SELECTED ASPECTS OF DEVELOPING AND PROTECTING THE LANDSCAPE OF SEPOLNO KRAJENSKIE COMMUNE
}

Slawomir Zawisza ${ }^{1}$, Dr. hab., Prof.; Piotr Prus ${ }^{2}, \mathrm{PhD}$ and Olga Herman ${ }^{3}$, B.Sc. $1,2,3$ UTP University of Science and Technology in Bydgoszcz, Poland

\begin{abstract}
Landscape development is an essential process for adequate area management. Landscape conservation aims at e.g. preserving its important elements, with areas of outstanding natural beauty, continuing traditions, cultural and historic customs and habits related to a place. The objective of the paper was to evaluate the actions taken and investments made so far by the commune in terms of developing and preserving the landscape space and learning the opinions of the commune residents and visitors. The research material was acquired from the analysis of the commune documents and the survey research made in 2017 in a group of 217 respondents. The documents analysed indicate a high level of EU investment co-funding in communes. The surveys have shown that the respondents appreciate the natural qualities of the commune area, however they also point to the threats posed to the attractiveness of the commune. Most of the respondents claimed that there had been an increase in the number of landscape development and protection actions after the integration with the European Union.
\end{abstract}

Key words: rural areas, landscape, preservation, natural environment.

JEL code: Q51, Q56, Q59.

\section{Introduction}

Landscape development is an important process affecting planning the space and adequate area management (Fjellstad W., 2009, Hamin E.M., 2002, Katsoni V., 2015, Montgomery D.R., 1995, Vinas C.D., 2017) and the evaluation of landscape development has been found in research papers for many years (Majtka K. et. al., 2012). Landscape preservation is the action for conserving the existing essential elements, such as the areas of outstanding natural beauty with rare flora and fauna species or characteristic natural topographical relief and continuing traditions, cultural and historic customs related to a place. The term „preservation” refers to preserving what already exists.

With a big need of bonding between the man and the natural environment in mind, a definition has been given to cover cultural landscape which, as provided in the law on historic monuments and preservation thereof, stands for the space perceived by people which includes nature elements and products of civilisation, historic sites due to the operation of natural factors and human impact (Ustawa ..., 2003). The cultural landscape covers not only physical elements but also, interestingly, non-material elements, to include local traditions and elements related to various areas of life, with holiday traditions, local outfits, dishes, customs, views and beliefs as well as the history of a place, characteristic for specific areas (Chi L., 2010, Chiang Y. et. al., 2013, Mantziou L., et. al., 2016, Middleton B.R. 2013, Katsoni V., 2015, Qin K. et. al, 2019).

Another concept is the landscape as a component of social and legal space. It is a set of norms, laws and objectives defined by the community residing in a given area. The laws as well as traditions and customs related to a given space are essential. To define such landscape, one can quote the statement that landscape, as a social and legal term, is a system of norms which regulate the principles of behaviour of the members of a given social group in reference to landscape (Kupidura A., Luczewski M., Kupidura P., 2011).

Another definition of landscape is the so-called mental landscape the psychology specialists are interested in. It is a subjective kind of landscape present inside each individual. It depends on

\footnotetext{
${ }^{1}$ Corresponding author. E-mail address: piotr.prus@utp.edu.pl
} 
individual values, principles, life experience and sensations of each person, it thus refers to the subjective observations and sensations of individuals possible thanks to senses.

In the European Union countries, in the 1990s an important guideline has been formulated by the concept of sustainable development (Adamowicz M., 2018, Bak I., Cheba K., 2018, Jankava A. et. al., 2017, Kalinowski S., Kielbasa B., 2017, Naglis-Liepa K. et. al., 2018), created as a response to a need of change in the the attitudes of people to the landscape surrounding them (Roman M. et. al., 2018), although the concept often faces numerous difficult-to-overcome implementation barriers (Dacko M., Dacko A., 2018). It refers to developing the existing resources of the areas of cities/ towns and villages through an adequate area management. The responsibility for developing the country's landscape should be held both at the national and communal level, as well as by the local communities formed by the residents of specific areas. It is in the local scale that a considerable part of the assumptions of sustainable development are executed (Wojewodzic T., 2005). It is thus important for the residents to be aware of how essential the effect they have on the area they live in. Polish communes should execute the concept of sustainable development also remembering the revitalisation of the degraded areas and places significant for the culture and history of the country (Kalinowski S., Kielbasa B., 2017, Kowalska M., Bogusz M., 2018).

The primary research objective has been to evaluate the commune's actions and investments in terms of developing and protecting the landscape space and learning the opinions of the commune residents and visitors. The aim of the survey study has been to diagnose the opinions of the respondents on identifying the greatest qualities and threats in terms of the development of the commune attractiveness, the occurrence of the structures and areas of preserved landscape and cultural heritage. The secondary research objective has been to learn the opinions of the respondents on increasing the number of actions to develop and to preserve the commune landscape after Poland's joining the European Union.

\section{Material and the research method}

The research was performed in August and September 2017. The general population included 16012 commune residents found in the register at the time of research. The maxim possible error accounted for $7 \%$, while the confidence level - $95 \%$. The sample to meet such requirements was made up of 217 respondents. For the survey there were selected 140 respondents living in the area of the towns and the villages in the commune, as well as 77 tourists and the persons visiting the commune on business. The research methods included the documents analysis and surveys carried out among the commune residents and tourists.

The research area covered the SepoINo Krajenskie commune, found in the north-western part of the kujawsko-pomorskie province, in Poland. SepolNo Krajenskie is the seat of the county authorities, it was granted the civic rights in 1360 and it currently covers the area of 22918 ha. The respondents were mostly at the age of $29(44.0 \%)$, followed by the age group of 30-39 (18.5\%), 50-59 (18.1\%) and at the age of $40-49(12.5 \%)$, whereas the lowest number of the respondents were at the age of 60 and more $(6.9 \%)$. The survey involved more women, who accounted for $58.3 \%$ of the respondents, than men (41.7\%). A great majority of the respondents $(64.4 \%)$ were the residents of the commune, and the other $26.9 \%$ - tourists and $8.7 \%$ - the persons on business. A majority of the population was represented by town residents (53.2\%). The residents of the villages located on the outskirts accounted for $24.8 \%$, while the suburban residents - for $22.0 \%$ of the respondents. 


\section{Research results and discussion}

In the SepolNo Krajenskie commune various commune landscape development and preservation investments have been completed (Budownictwo ..., 2018, Budzet ..., 2018, Finanse ..., 2018, Strategia ..., 2003). The amounts of investments are paid from the commune budget and various subsidising institutions. In 2006-2013 short-term investment projects were completed (executed within 1 year) at the total amount of PLN 39,539,145.87, of which the amount of the non-budget commune subsidies was PLN 22,338,688.50, which accounted for $56.5 \%$ of the total amount invested. In the commune in 2009-2013 there were also made long-term investments the execution of which was planned for more than 1 year; including the development of tourist and resort services as well as the development of sports and recreation facilities to cover the area of Krajenskie Lakeland, the revitalisation of the centre of SepolNo Krajenskie as well aa the construction and providing equipment to the creche as part of the complex of the Centre for a Small Children and Family in SepolNo Krajenskie. A total cost of the investments amounted to PLN 21,459,270.70, including PLN $13,373,504.60$ of co-funding outside the commune budget ( $62.3 \%)$. As indicated by the results of other studies, the residents of communes related much hope for enhancing infrastructure to using the European funds (Satola L., 2018). The execution of the EU co-funded investment projects facilitates the enhancement of the condition of technical, social and environmental infrastructure (Bieganska J., et. al., 2015, Dziekanski P., 2016, Dziekanski P., 2018, Ionescu H.M., et. al., 2016, Kancs D.A., 2005, Scorza F., 2013, Vujacic J.P., 2014). Currently the SepolNo Krajenskie commune provides many tourist trails (Turystyka, 2017). Some of them are related to the areas of the adjacent communes, which helps joint efforts of coordinating the tourist traffic. The trails go through the areas of outstanding natural beauty and sightseeing value; the commune's big asset are woodlands, lake shores, terrain elevations and river valleys. The trails also run through places with a high cultural and historic value, e.g. the palace in Komierowo or national memorials. The SepolNo Krajenskie commune stands from the crowd of the other communes by as many as 7 tourist trails (Szlaki ..., 2017). Despite a high number of trails, the said historic and cultural structures are not adequately displayed and they need revitalising.

According to the data available, the commune does not play a significant role in rendering services to tourists, even though it has numerous such qualities (Turystyka, 2017). During the study period the commune provided 370 beds, including two hotels, 4 leisure centres and 10 agritourism farms (Baza ..., 2017), however, a majority of them were not fully used due to a poor tourist traffic. The existing qualities create a potential for the commune development, however most of the commune assets, including the Krajenski Landscape Park (Krajenski ..., 2017), are not displayed enough. The commune tourism development potential is not, however, used enough, for example inadequate public management of the shores of numerous water reservoirs. As for the use of solar and wind energy, popular especially in the western countries; the Netherlands or Switzerland, to mention just a few, those resources are hardly used to generate energy in the SepolNo Krajenskie commune, especially due to the geographic location of the sepolenski county. However, thanks to the possibility of co-fundings from the National Fund for Environmental Protection and Water Management, solar structures are growing in number. In 2017 No wind farms emerged, however decisions were taken on the emergence of a few such structures in the upcoming years (Stupalkowski W., 2014).

The persons participating in the survey were aware of the natural qualities found in the commune. Similar results were recorded in other studies (Koreleska E., 2018). The greatest landscape assets of the SepolNo Krajenskie commune reported by most respondents $(50.2 \%)$, both the residents of 
towns and villages, were the lakes. Fewer, $27.9 \%$ of the respondents mentioned the forests. The present study, however, demonstrated that $11.2 \%$ of the persons considered a varied topographical relief as the landscape quality. The lowest number of the respondents $(0.5 \%)$, while listing the advantages, mentioned the historic sites in the area (Fig. 1).

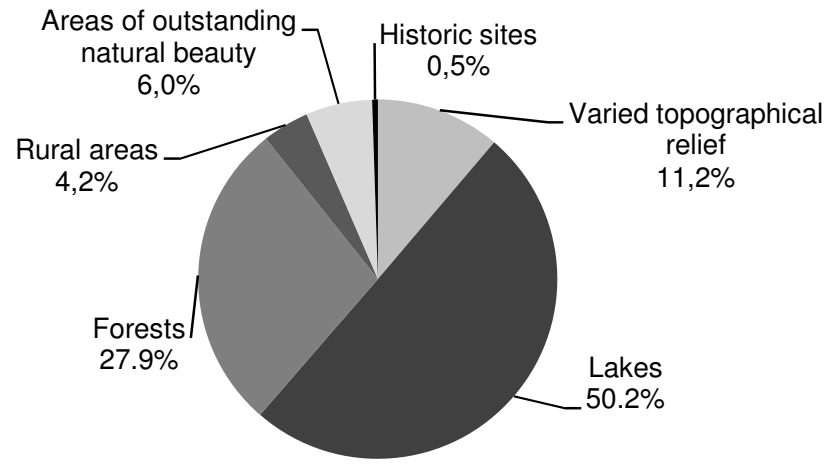

Source: author's calculations based on research

Fig. 1. The greatest advantages of the SepolNo Krajenskie commune landscape in the opinion of the respondents

Almost half of the respondents ( $46.4 \%$ ) answered that they knew of the existence of preserved landscape and cultural heritage in the commune. Slightly fewer (31.0\%) expressed a less definite opinion by saying "I think so", whereas only $6.9 \%$ said that that they did not think they knew of their existence, and only $0.9 \%$ definitely responded that they did not know of any such areas and structures. Also a group of respondents could hardly say anything about it (14.8\%) (Fig. 2).

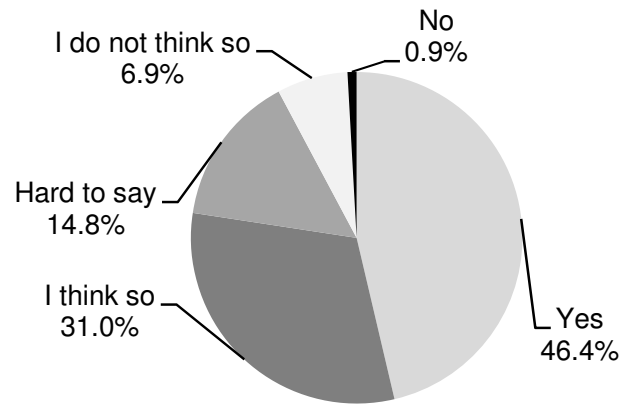

Source: author's calculations based on research

Fig. 2. Structures and areas of preserved landscape and cultural heritage in the commune in the opinion of the respondents

Among the threats lowering the attractiveness of the SepolNo Krajenskie commune, the highest share of the respondents $(23.9 \%)$ pointed to non-refurbished buildings. A similar group $(22.0 \%)$ considered the existence of the places which could be the commune's asset and which were neglected. Others pointed to neglecting the historic sites in the commune, which was indicated by $17.6 \%$ of the respondents. In the opinion of others, the biggest threats included rail routes closing down $(13.3 \%)$ and the outflow of tourists to more attractive communes (13.3\%). Almost every tenth respondent indicated an insufficient promotion as an essential reason for a lowered commune attractiveness (Fig. 3). 


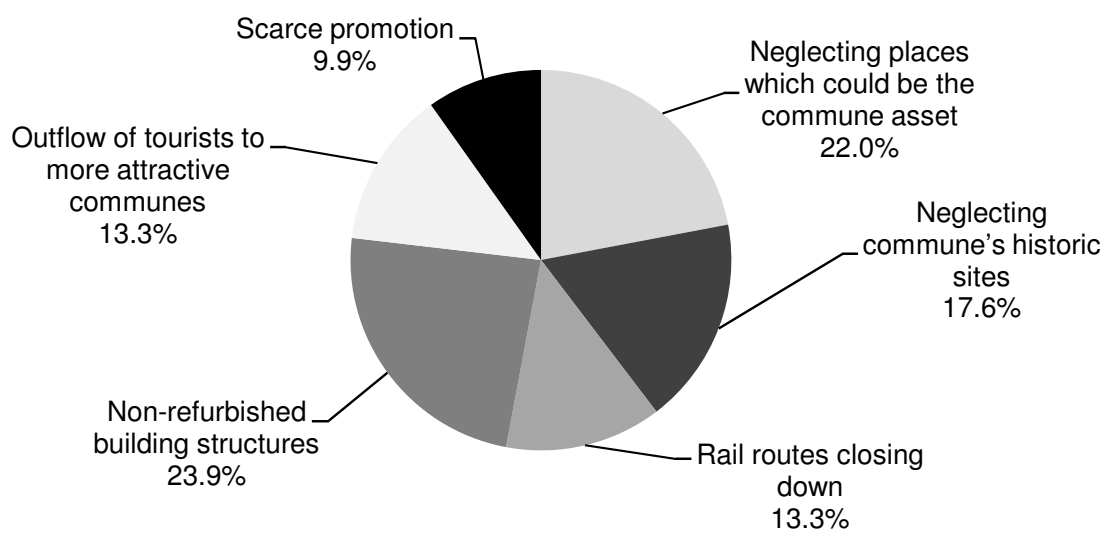

Source: author's calculations based on research

Fig. 3. Existing threats which, in the opinion of the respondents, decrease the attractiveness of the SepolNo Krajenskie commune most

For the way people perceive the landscape attractiveness, the closest surroundings where people live are most essential. Answering the question on the negative impact of much freedom in the building style, including a free selection of facade materials and colours in the commune, a vast majority $(69.5 \%)$ confirmed that it had a negative impact on the landscape. A few respondents, only $6.0 \%$, stated that the free choice in construction decisions had No negative effect on the commune landscape and $13.0 \%$ answered "I do not think so". For $11.6 \%$ of the respondents it was hard to say if the effect was positive or negative for the surroundings.

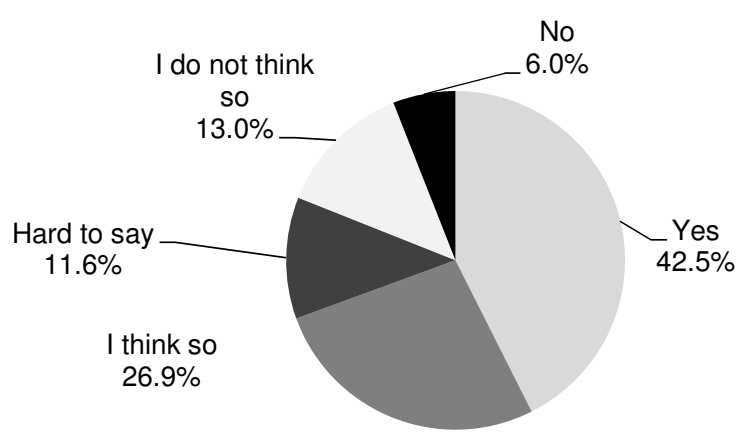

Source: author's calculations based on research

Fig. 4. Negative effect of much freedom in the building style, with the selection of any facade materials and colours on the landscape in the opinion of the respondents

Another question concerned evaluating the effect of a large number of advertisement displays along the roads, in the town and in the rural areas of the SepolNo Krajenskie commune, on the landscape. The highest number of the respondents ( $43.5 \%$ ) claimed that too many displays had a negative effect on the landscape, while $23.2 \%$ responded that they thought they had more of a negative effect. A much smaller part of the respondents (15.7\%) claimed that they did not think it had much of a negative effect on the landscape, whereas $3.7 \%$ of the respondents said that it did not have a negative effect on the surroundings. Of the population researched, $13.9 \%$ of the respondents refrained from giving a definite answer to the question (Fig. 5). 


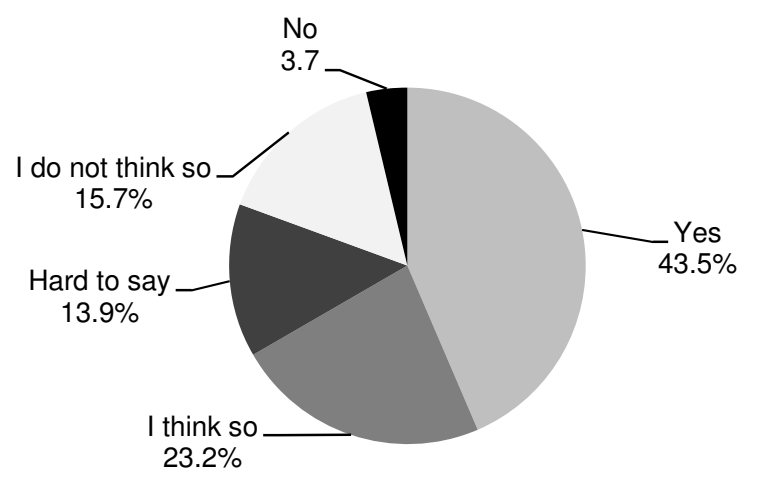

Source: author's calculations based on research

Fig. 5. Negative effect of a large number of advertisement displays along the roads in the town and in the commune on the landscape in the opinion of the respondents

To answer the question about the observable number of actions to develop and to protect the commune landscape after Poland's joining the European Union, only $5.1 \%$ did not notice any such actions, while $20.9 \%$ did not think they noticed any. $25.6 \%$ of the respondents thought they noticed their intensity increased, whereas $24.7 \%$ marked a higher number of such actions after 1 May 2004 (Fig. 6).

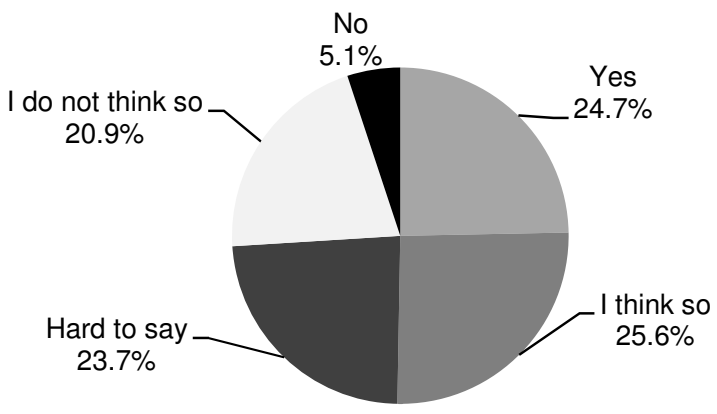

Source: author's calculations based on research

Fig. 6. Opinions of the respondents on an increasing number of actions to develop and to protect the commune landscape after Poland joined the European Union

\section{Conclusions}

1) In spatial planning, many countries, both the EU and non-EU member states, follow the principles of sustainable development. It is the concept many countries of today's Europe build their strategies on. One of the principles provides for the respect for the area the man lives in. It advocates the selection of the adequate investments for a given place, considering both the nature factors, including the topographical relief, as well as the history, traditions and culture of the place.

2) For the SepolNo Krajenskie commune, Poland's joining the European Union was essential as it facilitated the acquisition of additional funds for the commune development, also in terms of landscape development and preservation. The documents analysed, provided by the commune authorities, show a high level of co-funding for the investment projects executed in 2006-2013 with the EU funds, accounting for $56.5 \%$ short-term and $62.3 \%$ long-terms investment costs.

3) The respondents taking part in the survey appreciated the nature qualities of the commune, mostly lakes, forests and the topographical relief, with a majority claiming to be knowledgeable about the structures and areas of preserved landscape and cultural heritage. 
4) The threats to the commune attractiveness were most frequently considered to be posed by nonrefurbished building structures, neglecting the places which could be the commune assets as well as No adequate attentiveness to historic sites. Most of the survey respondents claimed a negative effect of much freedom in the building style, related to a free choice of facade materials and colours as well as a high number of advertisement displays along the roads in the town and in the entire commune.

5) Most of the respondents believed that the number of landscape development and preservation actions as a result of the integration with the European Union would increase.

\section{Bibliography}

1. Adamowicz, M. (2018). Normative Aspects of Rural Development Strategy and Policy in the European Union. Proceedings of the International Conference "Economic Science for Rural Development", Jelgava, Latvia, No 47, pp. 17-27.

2. Bak, I., Cheba, K. (2018). The Application of the Dynamic Classifications in Order to Evaluate the Changes of the European Union's Sustainable Development. Proceedings of the International Conference "Economic Science for Rural Development", Jelgava, Latvia, No 48, pp. 36-43.

3. Baza noclegowa (Accommodation Base) (2017). Retrieved: https://www.gminasepolno.pl/index.php/cos2/12-strona/66-baza-noclegowa Access: 20.12.2018.

4. Bieganska, J., Sroda-Murawska, S., Grzelak-Kostulska, E. (2015). Significance of EU Funds in the Creation of Sport and Recreation Infrastructure in Poland in the Context of the Cohesion Policy. Proceedings of the 17th International Colloquium on Regional Sciences, Hustopece, Czech Republic, pp. 409-416.

5. Budownictwo i inwestycje (Construction and Investments) (2018). Retrieved: http://www.bip.gminasepolno.pl/?cid=907 Access: 20.12.2018.

6. Budzet (Budget) (2018). Retrieved: http://www.bip.gmina-sepolno.pl/?cid=28 Access: 20.12.2018.

7. Chi, L., (2010). Planning and Management of Cultural Heritage Sites and Landscape of Surrounding Cities and Towns-Taking the Zhoukoudian Peking Man Site for Example. Proceedings of the 47th International Federation of Landscape Architects (IFLA) World Congress, Zuzhou, China, pp. 1-7.

8. Chiang, Y., Weng, P., Sato, N. (2013). The Preservation of Important Rural Japanese Cultural LandscapesConsidering the WarabiNo Paddy Field as an Example. Journal of the Faculty of Agriculture, Kyushu University, 58(1), 209-218.

9. Dacko, M., Dacko, A., (2018). Studia nad rozwojem obszarow wiejskich - od paradygmatu wzrostu do rezyliencji (Studies on the Development of Rural Areas - from the Growth Paradigm to Resilience). Wies $i$ Rolnictwo, 2(179), pp. 49-64.

10. Dziekanski, p. (2016). Spatial Changes and Assessment of the Financial Condition of Local Government Units in the Context of the Income Structure. Proceedings of the International Conference on Management Trends of Management in the Contemporary Society, Brno, pp. 153-156.

11. Dziekanski, p. (2018). Territorialisation of Spatial Disproportions of Infrastructure and Development of Rural Areas of the Swietokrzyskie Voivodship. Proceedings of the International Conference "Economic Science for Rural Development", Jelgava, Latvia, No 47, pp. 73-80.

12. Finanse gminy (Municipal Finance) (2018). Retrieved: http://www.bip.gmina-sepolno.pl/?cid=330 Access: 20.12.2018.

13. Fjellstad, W., Mittenzwei, K., Dramstad, W., Ovren, E. (2009). Landscape Protection as a Tool for Managing Agricultural Landscapes in Norway. Environmental Science \& Policy, 12(8), pp. 1144-1152.

14. Hamin, E. M. (2002). Western European Landscape Protection Western European Approaches to Landscape Protection: A Review of the Literature. Journal of Planning Literature, 16(3), pp. 339-358.

15. Ionescu, H. M., Burduja, S. I., \& Burlacu, F. A. (2016). Improved Prioritization Criteria for Road Infrastructure Projects. Romanian Journal of Transport Infrastructure, 5(2), pp. 10-27.

16. Jankava, A., Parsova, V., Berzina, M., Didrihsone, D., Platonova. D., Palabinska, A. (2017). Assessment of Land Degradation for Sustainable Development of Municipality Territories. Proceedings of the International Conference "Economic Science for Rural Development", Jelgava, Latvia, No 44, pp. 69-75.

17. Kalinowski, S., Kielbasa, B. (2017). Risk of Poverty and Social Exclusion in The European Union in The Context of Sustainable Development. Proceedings of the 8th International Scientific Conference Rural Development 2017, Kaunas, pp. 1060-1064.

18. Katsoni V. (2015) Application of a Cultural Landscape Tourism Marketing Management Approach in a Mountainous Area. In: Katsoni V. (eds) Cultural Tourism in a Digital Era. Springer Proceedings in Business and Economics. Springer, Cham, pp. 121-130.

19. Kancs, D. A. (2005). Efficiency of European Funds in the Accession Countries: the Case of Transport Infrastructure Investments in Latvia. Transportation Planning and Technology, 28(4), pp. 293-313.

20. Koreleska, E. (2018). Ausgewahlte Marketingaspekte von Non-Profit-Organisationen in landlichen Gebieten (Selected Marketing Aspects of Non-Profit Organizations in Rural Areas). Journal of Research and Applications in Agricultural Engineering, 63 (2), pp. 120-123. 
21. Kowalska M., Bogusz M., (2018). Assumptions of Sustainable Tourism in the Context of Ecological Awareness. Journal of Landscape Management, 9(1), pp. 22-27.

22. Krajenski Park Krajobrazowy (Krajenski Landscape Park) (2017). Retrieved: https://www.gminasepolno.pl/index.php/cos2/12-strona/246-krajenski-park-krajobrazowy Access: 20.12.2018.

23. Kupidura, A., Luczewski, M., Kupidura, P., (2011). Wartosc krajobrazu. Rozwoj przestrzeni obszarow wiejskich (Landscape Value. Development of Rural Areas). PWN Warszawa.

24. Majtka, K., Bukowski, G., Koreleska, E. (2012). Ocena krajobrazowa i florystyczna wybranych gospodarstw ekologicznych i konwencjonalnych z regionu Pojezierza Brodnickiego i Doliny Dolnej Wisly (Floristic Evaluation of Organic and Conventional Farms from the Region of the Brodnica Lake District and the Valley of the Low Vistula River), Architektura Krajobrazu, 3, pp. 44-54.

25. Mantziou, L., Kontopoulou, E., Hatzakis, C. O. (2016). Sustainable Development Protects Sensitive Cultural Landscapes. Procedia engineering, 161, pp. 1785-1790.

26. Middleton, B. R. (2013). "Just Another Hoop to Jump Through?” Using Environmental Laws and Processes to Protect Indigenous Rights. Environmental Management, 52(5), pp. 1057-1070.

27. Montgomery, D. R. (1995). Input-and Output-Oriented Approaches to Implementing Ecosystem Management. Environmental Management, 19(2), pp. 183-188.

28. Naglis-Liepa, K., Popluga, D., Lenerts, A., Rivza, P., Kreismane, D. (2018). Integrated Impact Assessment of Agricultural GHG Abatement Measures. Proceedings of the International Conference "Economic Science for Rural Development", Jelgava, Latvia, No 49, pp. 77-83.

29. Qin, K., Li, J., Liu, J., Yan, L., Huang, H. (2019). Setting Conservation Priorities Based on Ecosystem Services-A Case Study of the Guanzhong-Tianshui Economic Region. Science of The Total Environment, 650, pp. 3062-3074.

30. Roman M., Roman M., Roman K. (2018). The Forecast of Economic Processes of Selected Agricultural Products in the Development of Bioenergy and Agritourism Activity in Poland. Proceedings of the International Scientific Conference Hradec Economic Days,University of Hradec Kralove, Hradec Kralove, 8 (2), pp. 246-257.

31.Scorza, F. (2013). Improving EU Cohesion Policy: the Spatial Distribution Analysis of Regional Development Investments Funded by EU Structural Funds 2007/2013 in Italy. Proceedings of the 13th International Conference on Computational Science and Its Applications (ICCSA), Ho Chi Minh City, Vietnam, pp. 582593.

32. Satola, L., (2018). Local Offer of Public Services in the Perception of Municipalities' Residents. Conference Proceedings of the International Scientific Days 2018 "Towards Productive, Sustainable and Resilient Global Agriculture and Food Systems", Nitra, pp. 1403-1412.

33. Strategia rozwoju Gminy SepolNo Krajenskie (Development Strategy of the SepolNo Krajenskie Commune) (2003). Retrieved: http://www.bip.gmina-sepolno.pl/?cid=10\&bip_id=299 Access: 20.12.2018.

34.Stupalkowski, W., (2014). Program Ochrony Srodowiska Gminy SepolNo Krajenskie aktualizacja na lata 2014-2017 z perspektywa na lata 2018-2021 (Environmental Protection Program of the SepolNo Krajenskie Commune Update for 2014-2017 with a Perspective for 2018-2021). UMiG, SepolNo Krajenskie.

35.Szlaki turystyczne (Tourist Routes) (2017). Retrieved: https://www.gmina-sepolno.pl/index.php/cos2/12strona/245-szlaki-turystyczne Access: 20.12.2018.

36. Turystyka (Tourism) (2017). Retrieved: https://www.gmina-sepolno.pl/index.php/cos2 Access: 20.12.2018.

37. Ustawa z dnia 23 lipca 2003 r. o ochronie zabytkow i opiece nad zabytkami (The Act of 23 July 2003 on the Protection of Monuments and the Protection of Monuments). Dz.U. 2003 nr 162 poz. 1568.

38. Vinas, C.D., (2017). Consideration and Processing of Agricultural Landscapes in the Instruments of Environmental Protection, Land Management And Urban Planning. Cantabria (Spain) As A Case Of Study. Boletin de la Asociacion de Geografos Espanoles, 75, pp. 373-405.

39. Vujacic, J. p. (2014). Innovative Financing of Transport Infrastructure and Economic Growth. Proceedings of the 2nd International Conference on Traffic and Transport Engineering (ICTTE). Belgrade, Serbia, pp. 575582.

40. Wojewodzic, T., (2005). An Attempt at Construction of a Standard of Development Balancing on the Level of Local Government Units. Proceedings of the 2nd International Scientific Conference on Rural Development: Globalisation and Integration Challenges to Rural Development in Eastern and Central Europe, Kaunas, Lithuania, Vol 2, Book 1, pp. 184-186. 